\title{
Principles of pseudofeces rejection on the bivalve mantle: integration in particle processing
}

\author{
Peter G. Beninger ${ }^{1, *}$, Anne Veniot ${ }^{2}$, Yves Poussart ${ }^{2}$ \\ ${ }^{1}$ Laboratoire de Biologie Marine, Faculté des Sciences, Université de Nantes, F-44322 Nantes Cédex 3, France \\ ${ }^{2}$ Département de Biologie, Faculté des Sciences, Université de Moncton, Moncton, New Brunswick E1A 3E9, Canada
}

\begin{abstract}
Mechanisms of pseudofeces voidance from the mantle were investigated in 3 of the 4 major bivalve particle processing systems using scanning electron microscopy, to determine what mechanisms permit the isolation of pseudofeces transport in bivalves presenting discrete mantle rejection pathways, and how this contrasts with species which do not possess such pathways. The entire mantle surfaces of Mytilus edulis (homorhabdic filibranch), Mya arenaria and Spisula solidissima (eulamellibranchs), and Placopecten magellanicus (heterorhabdic filibranch) were surveyed and photographed. In both the homorhabdic filibranchs and the eulamellibranchs, the mantle rejection tracts previously located using video endoscopy were characterized by cilia which were extraordinarily long compared to the cilia of the general pallial surface. These long cilia were grouped into closely adhering tufts, herein termed composite cilia. In $M$. edulis and $M$. arenaria, the general pallial surface presented shorter simple cilia, whereas in $S$. solidissima the general pallial surface presented simple cilia dorsally, long composite cilia ventrally, and an intermediate band of short composite cilia. These 3 species all possess a gill ventral particle groove; hence the site of pseudofeces production is the labial palp, and a discrete mantle rejection tract is necessary to transport pseudofeces to the inhalent siphon for expulsion. The long composite cilia within this tract may provide vertical isolation of pseudofeces from the general pallial surface; effective mucociliary transport using such long cilia can only be accomplished if they are grouped, as in all 3 species with mantle rejection tracts. In the heterorhabdic filibranch $P$. magellanicus, no specialized cilia were observed on the mantle; this corresponds to the absence of a mantle rejection tract in this system, which does not possess a gill ventral particle groove and relies on valve adduction to expel pseudofeces. These results suggest that elevation above the surrounding mantle cilia is the rule in species relying on mantle rejection tracts for the voidance of pseudofeces. These results show the usefullness of cilia mapping in the study of bivalve suspension-feeding mechanisms.
\end{abstract}

KEY WORDS: Bivalves - Feeding · Pseudofeces - Rejection

\section{INTRODUCTION}

Among the free-living aquatic invertebrates, suspension-feeding is a widespread and successful trophic strategy, spanning phyla from the Porifera to the Chordata (Jørgensen 1966). Two of the foremost problems faced by organisms which have adopted this mode of feeding are (1) the regulation of the volume of material processed and ingested (ingestion volume regulation), and (2) the sorting of edible seston from that which is inorganic, of low nutritional value, or even toxic (selection) (Sierszen \& Frost 1992). In suspension-feeding

\footnotetext{
•E-mail: peter.beninger@svt.univ-nantes.fr
}

bivalves, both of these processes culminate in rejection, which results in the formation of pre-ingestive rejecta termed pseudofeces. The production and voidance of pseudofeces is thus an important physiological function (Owen 1966, Bayne \& Newell 1983, Iglesias et al. 1992), as well as being a major contributor to bivalve biodeposits in the aquatic ecosystem (Bayne \& Newell 1983, Kautsky \& Evans 1987, Dame 1993).

Pseudofeces elimination is the final rejection step in the cascade of particle processing events which begin with capture on the gill. One of the salient conclusions from the intense research effort in the field of bivalve feeding mechanisms (e.g. Beninger et al. 1992, 1997a, Tankersley \& Dimock 1993, Ward et al. 1993) is that 
the type of particle processing, and hence the mode of pseudofeces rejection, is initially determined by the gill type itself (Beninger \& St-Jean 1997a). Endoscopic observation of whole specimens has demonstrated that pseudofeces rejection involves well-defined mantle rejection tracts in bivalves presenting 2 of the 4 gill types: homorhabdic filibranch and eulamellibranch (Table 1). In the homorhabdic filibranch Mytilus edulis, the mantle rejection tract presents an extraordinary density of acid mucopolysaccharide (AMPS)-secreting mucocytes (Ansell 1961, Beninger \& St-Jean 1997b), which anchors the pseudofeces to the ciliated epithelium and hence enables the transport of pseudofeces counter to the prevailing pallial current (Beninger \& St-Jean 1997b).

It has long been known that the general pallial surface of the mantle is ciliated, and pseudofecal transport has often been observed in dissected specimens (Wallengren 1905, Orton 1912, Kellogg 1915, Elsey 1935, Ansell 1961, Foster-Smith 1975). Recent comparisons with endoscopic observations have shown that pseudofeces transport on the mantle appears unaffected by dissection, validating the simpler technique of observation of inert particles deposited on the mantle (Beninger \& St-Jean 1997b, Beninger et al. 1997a). The transport of pseudofeces along well-defined rejection tracts situated on the general ciliated pallial surface raises the possibility of some form of isolation mechanism which would confine pseudofeces transport to these tracts, such as ciliary specialization, in addition to the aforementioned specialization of mucocyte types and densities. Although the presence of cilia is frequently documented in studies dealing with the mantle pallial surface (e.g. Morrisson 1993, Reindl \& Haszprunar 1996), no comprehensive survey of mantle ciliation has been performed, and hence very little information is available concerning the possible specialization of cilia (either in type or density) in the mantle rejection tracts. Based on histological observations, Ansell (1961) stated that cilia on the mantle rejection tract of several species of Veneridae were longer than those outside the rejection tract; this poses the problem of functionality, since long cilia have inherent limitations to effective mucociliary transport (Sleigh et al. 1988, Sleigh 1989). Given the importance of rejection in particle processing, we have performed a detailed survey of the ciliation of the bivalve pallial surface, using the technique of ciliary mapping (Beninger et al. 1995). The present study reports on the ciliary types and distribution on the mantle pallial surface of Mytilus edulis (homorhabdic filibranch), Placopecten magellanicus (heterorhabdic filibranch), and Mya arenaria and Spisula solidissima (eulamellibranchs), and relates these data to the rejection mechanisms in these species.

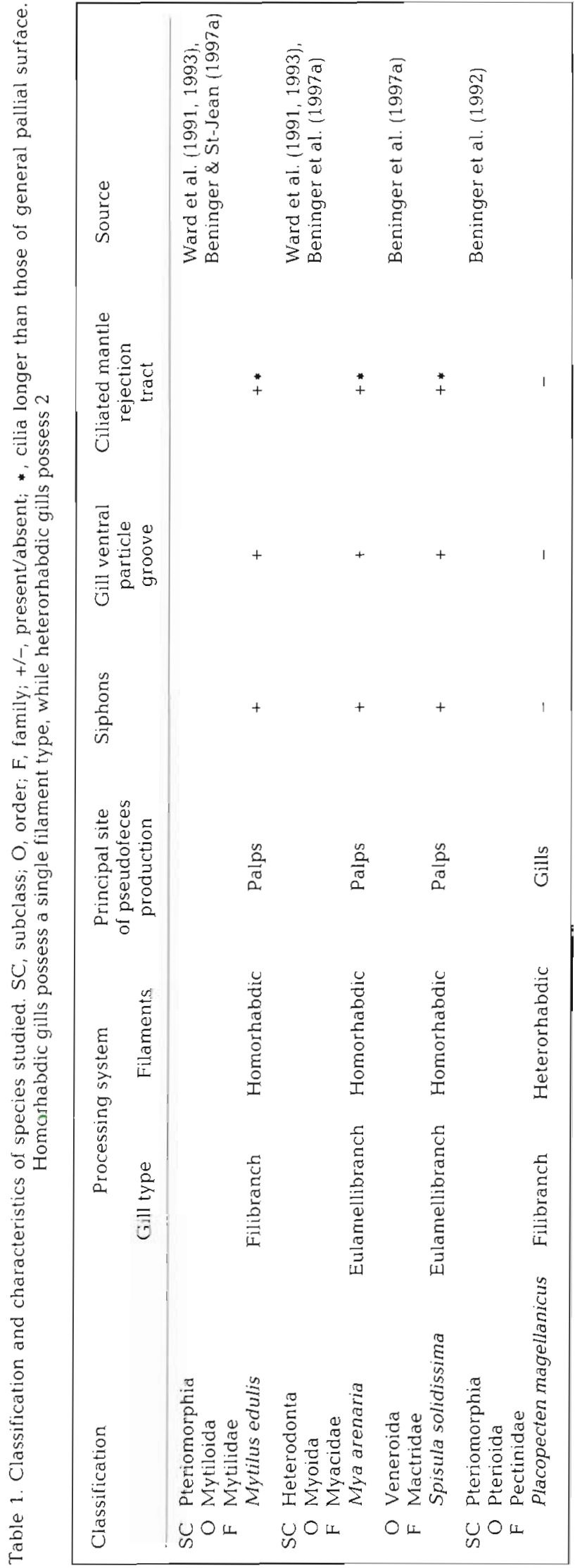




\section{MATERIAL AND METHODS}

Sampling and fixation. The size range of specimens was limited to individuals $\leq 30 \mathrm{~mm}$ (maximum size possible for observation of whole specimens in the SEM specimen chamber). Mya arenaria (size range 15.3 to $30.0 \mathrm{~mm}$ antero-posterior axis) and Mytilus edulis (20.0 to $27.0 \mathrm{~mm}$ antero-posterior axis) were obtained from the intertidal on 24 May and 16 July 1996 in Passamaquoddy Bay, New Brunswick, Canada $\left(45^{\circ} 07^{\prime} \mathrm{N}, 67^{\circ} 05^{\prime} \mathrm{W}\right)$. Placopecten magellanicus (size range 26 to $30 \mathrm{~mm}$ antero-posterior axis) were captured via SCUBA from the same site in the subtidal on 16 August 1996. Specimens of Spisula solidissima were obtained at low tide on 5 June 1996 in Shediac Bay, New Brunswick $\left(46^{\circ} 13^{\prime} \mathrm{N}, 64^{\circ} 29^{\prime} \mathrm{W}\right.$ ), as well as on 16 June 1996 in Passamaquoddy Bay.

The adductor muscles of each individual of Mya arenaria, Spisula solidissima, and Mytilus edulis were sectioned in the field, and specimens were immediately fixed in a hypertonic solution of cold $2.5 \%$ glutaraldehyde-sodium cacodylate buffer according to the protocol of Beninger et al. (1995). Specimens of Placopecten magellanicus were transported to the laboratory in insulated coolers containing well-oxygenated seawater from the sampling site prior to treatment as above.

On the sampling dates indicated above, all specimens showed intense gametogenic activity, and it was often not possible to avoid small lesions to the mantle during dissection of such small specimens prior to fixation. Mytilus edulis, Mya arenaria, and Spisula solidissima all present gonadic infiltration of the mantle when ripe, and gametes were thus unavoidably shed onto the mantle in some cases; this does not alter the observations of the present study, but does explain the presence of such particles in some micrographs.

Specimen processing. Specimens were fixed for a minimum of $48 \mathrm{~h}$ and partially dehydrated in an ascending ethanol series to $70 \%$ ethanol. At this point the visceral mass was removed under a dissecting microscope using micro-surgical instruments, in order to expose the entire mantle surface. The dissected specimen was further dehydrated to $100 \%$ spectroscopy-grade anhydrous ethanol, critical-point dried in liquid 'bone-dry' $\mathrm{CO}_{2}$, placed on an SEM stub with silver paint, and sputter-coated with gold.

SEM observations were performed using a JEOL JSM 5200, equipped with both still camera and video port. Detailed observations were made of the entire mantle for each species, from the margin to the junction of the gill axis. Narrated Hi-8 video recordings were performed and maintained as permanent records for each specimen, and photographs were obtained using the $4 \times 5$ " format Polaroid Land camera.

\section{RESULTS}

\section{Cilia types}

Two types of cilia were distinguished, based on occurrence as single cilia or as discrete groups of closely adhering cilia, which we here term 'composite cilia' Within these 2 types, categories were established according to length; these 2 characteristics produced the following classification:

Short simple cilia (SSC): individual cilia $<5 \mu \mathrm{m}$

Simple cilia (SC): individual cilia 5 to $15 \mu \mathrm{m}$

Long simple cilia (LSC): individual cilia $>15 \mu \mathrm{m}$

Composite cilia (CC): group of closely adhering cilia

10 to $15 \mu \mathrm{m}$

Long composite cilia (LCC): group of closely adhering cilia $>15 \mu \mathrm{m}$

It should be noted that these are lengths measured directly on SEM micrographs, and do not take into account fixation shrinkage (approx. 15 to 20\%; H. Silverman, Dept of Biological Sciences, Louisiana State University, Baton Rouge, Louisiana, unpubl. obs.) and the height of the microvillar layer (Beninger et al. 1997 b).

None of the cilia observed presented artefactual anomalies such as paddle cilia (Beninger et al. 1995), indicating that fixation and SEM processing did not alter surface features

\section{Mytilus edulis (Fig. 1)}

The mantle ciliation of Mytilus edulis presented uniformly dense SSC approx. $5 \mu \mathrm{m}$ in length, with a discrete antero-posterior band of CC approx. $20 \mu \mathrm{m}$ long, situated slightly ventral to the gill-mantle junction and extending to the ventralmost point of the base of the inhalent siphon (Fig. $1 \mathrm{a}-\mathrm{c}, \mathrm{e}$ ). At the base of the gill junction, the uniform cover of dense SSC became patchy (Fig. 1b), and the gill filaments themselves presented isolated groups of LSC (Fig. 1f).

The individual cilia of the $\mathrm{CC}$ adhered closely to each other for approximately half of their length, diverging toward their distal extremities (Fig. 1d).

\section{Mya arenaria (Fig. 2)}

The mantle ciliation of Mya arenaria presented 2 distinct regions: SC approx. $10 \mu \mathrm{m}$ long from the hinge region of the mantle (which also corresponded to the gill junction in this species) to the dorsalmost point of the base of the inhalent siphon (Fig. 2a-c,e), and CC similar to those of Mytilus edulis from this point to the 
a
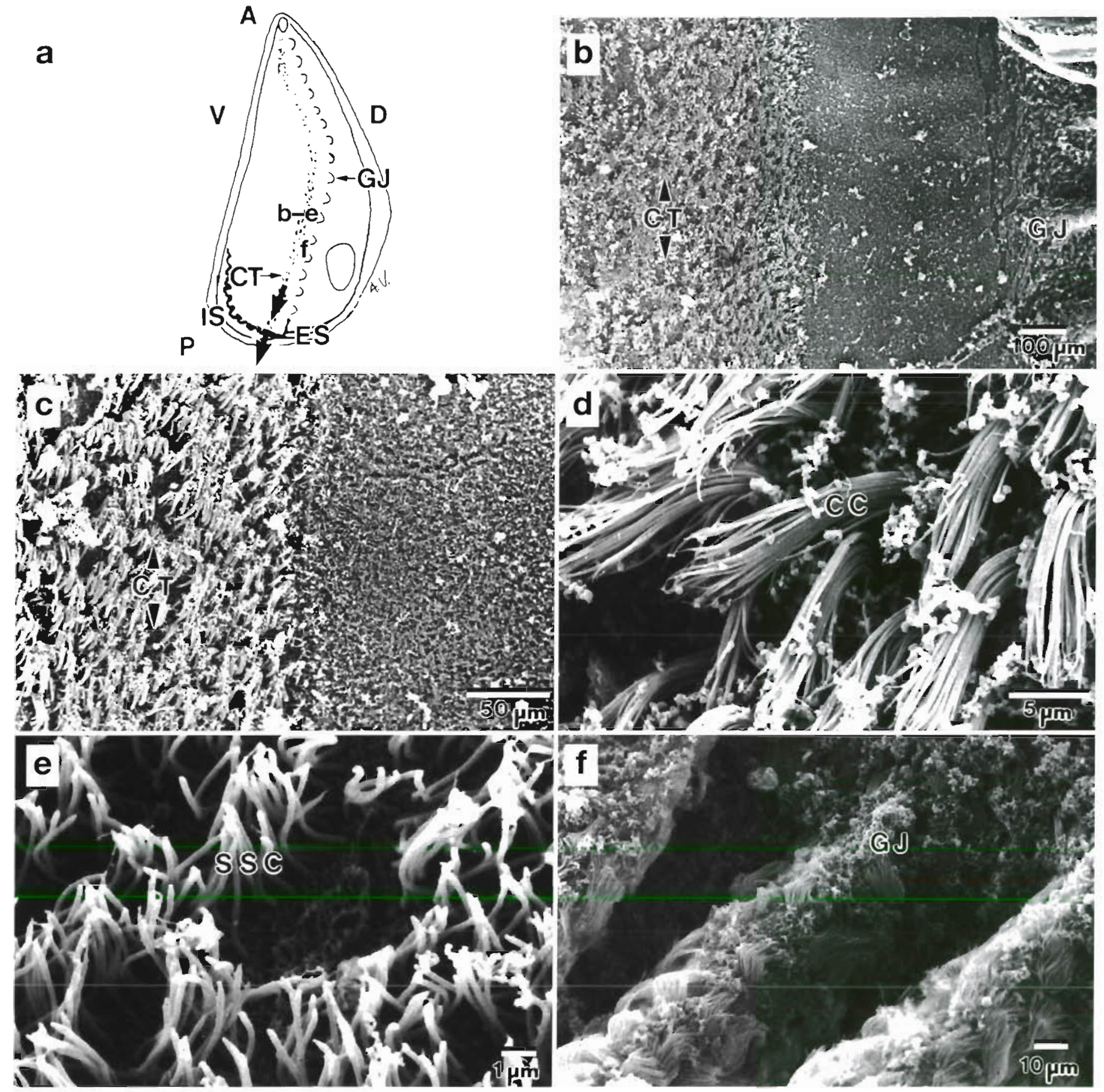

Fig. 1. Mytilus edulis mantle ciliation. (a) Location of ciliated mantle rejection tract (CT) in relation to gill junction with the mantle (GJ) and inhalent siphon (IS). A, D, P, V: anterior, dorsal, posterior, and ventral orientations, respectively. Specimen oriented with ciliated tracts as in subsequent micrographs. Lower-case letters (b to f) designate locations of corresponding scanning electron micrographs (SEM); large arrows show direction of pseudofeces transport. (b) Low-power aspect of ciliated mantle rejection tract (CT), clearly visible and separated from the gill-mantle junction (GJ) by an apparently smoother band. (c) Detail of ciliated mantle rejection tract (CT), showing groups of cilia, and the adjacent band presenting a dense cover of shorter cilia. (d) Detail of composite cilia (CC) within the ciliated mantle rejection tract. (e) Detail of short simple cilia (SSC) in adjacent band. (f) Detail of mixed ciliation at junction of gill filaments to mantle (GJ). Densely ciliated abfrontal surface of gill filaments (typical of $M$. edulis) visible 


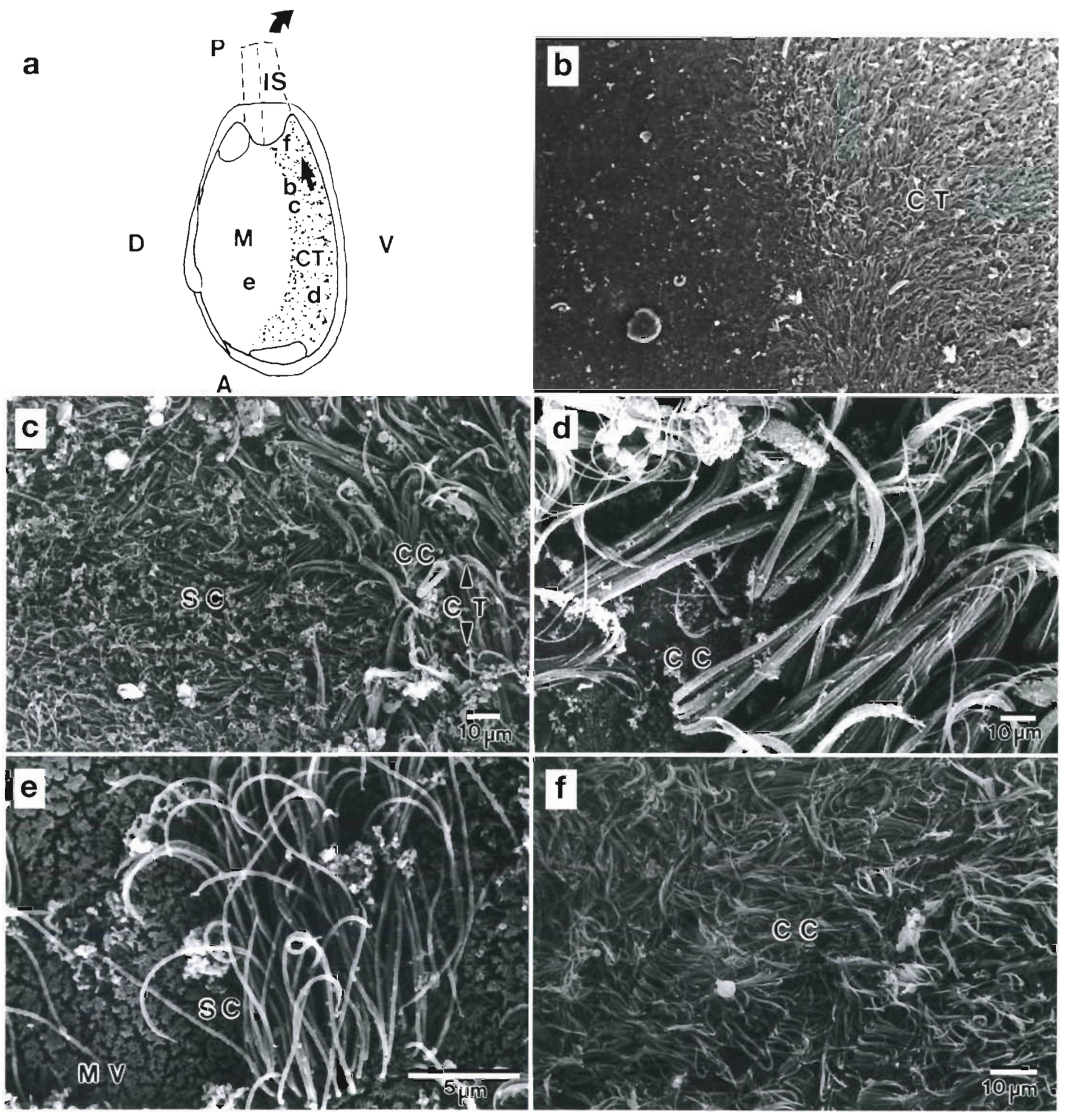

Fig. 2. Mya arenaria mantle ciliation. (a) Location of ciliated mantle rejection tract (CT) in relation to general mantle surface (M) and inhalent siphon (IS). A, D, P, V: anterior, dorsal, posterior, and ventral orientations, respectively. Specimen oriented as in subsequent micrographs. Lower-case letters (b to f) designate locations of corresponding SEM; large arrows show direction of pseudofeces transport. (b) Low-power SEM of ciliated mantle rejection tract (CT), and apparently smoother adjacent general mantle surface. (c) Detail of (b) showing composite cilia (CC) of ciliated mantle rejection tract (CT), and simple cilia of general mantle surface (SC). (d) Detail of composite cilia (CC) within ciliated mantle rejection tract. (e) Detail of tufts of simple cilia (SC) on the general mantle surface. Microvilli (MV) are visible between tufts and between cilia of a tuft. (f) Dense cover of composite cilia $(\mathrm{CC})$ at the base of the inhalent siphon 
a

A

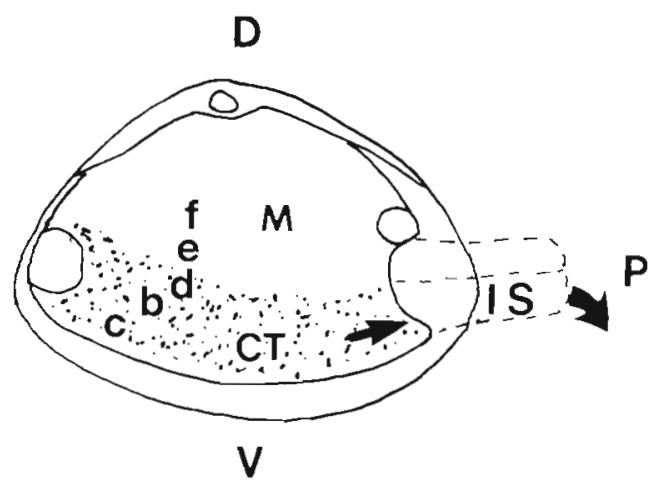

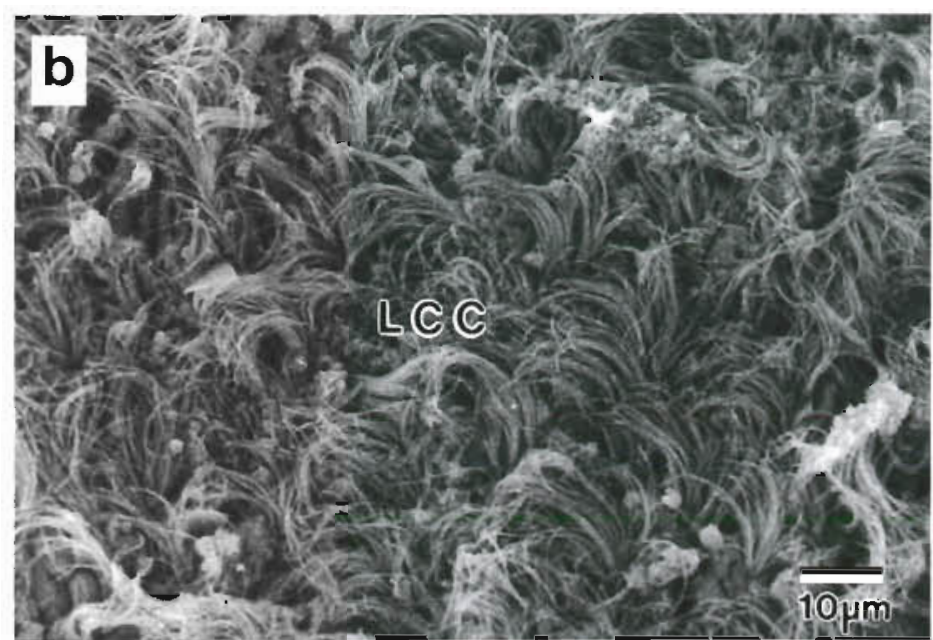
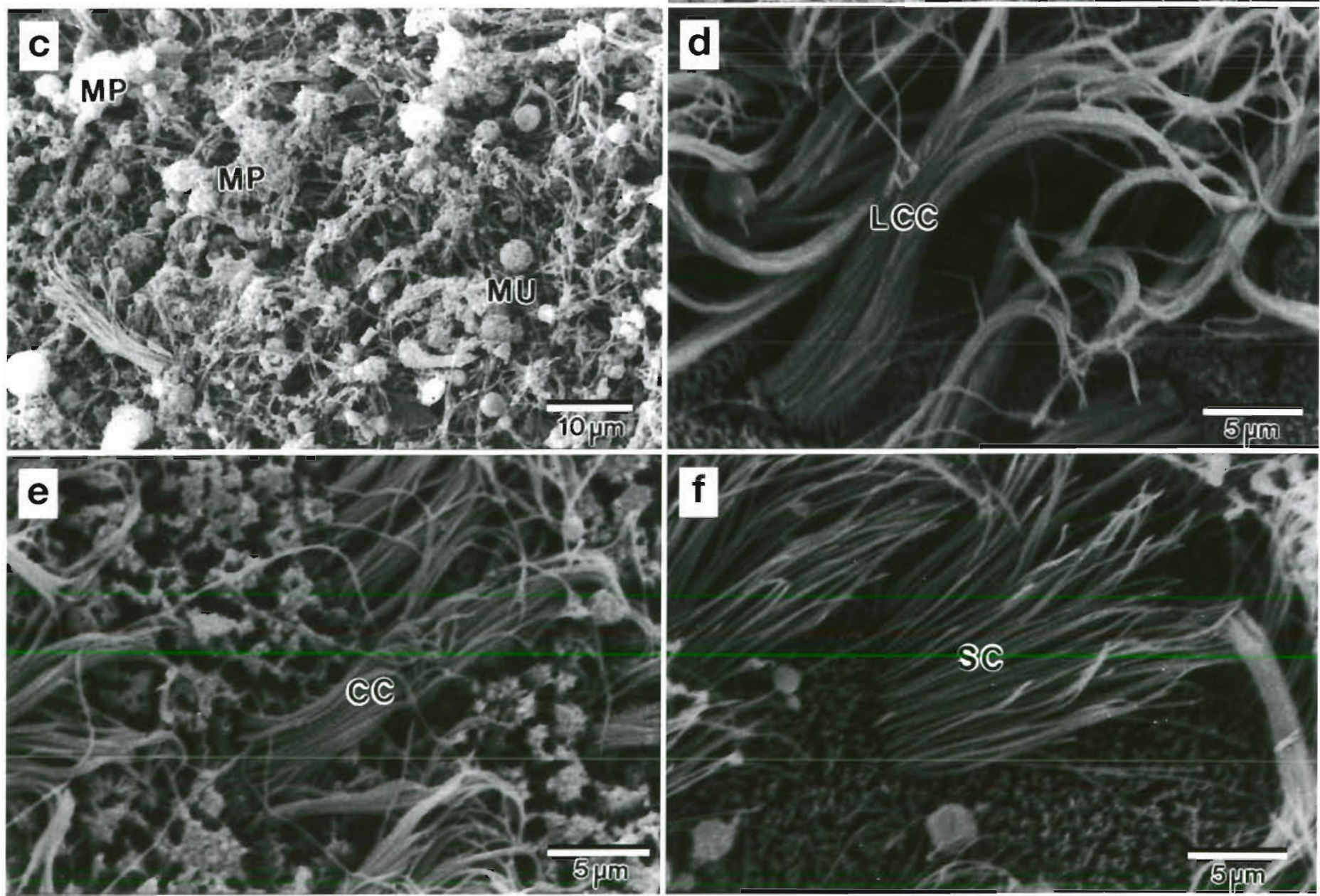

Fig. 3. Spisula solidissima mantle ciliation. (a) Location of ciliated mantle rejection tract (CT) in relation to general mantle surface (M), and inhalent siphon (IS\}. A, D, P, V: anterior, dorsal, posterior and ventral orientations, respectively. Specimen oriented as in subsequent micrographs. Lower-case letters ( $b$ to $f$ ) designate locations of corresponding SEM; large arrows show direction of pseudofeces transport. (b) Dense long composite cilia (LCC) cover of mantle rejection tract. (c) Mucus-particle masses (MP) and mucus balls (MU) representing dehydrated residue of mucus-particle raft characteristic of mucociliary transport in ciliated mantle rejection tract. (d) Detail of cilia within ciliated mantle rejection tract, showing them to be of the long composite cilia type (LCC). (e) Detail of cilia on the intermediate band of the general mantle surface, showing them to be of the composite cilia type (CC). (e) Detail of cilia in the dorsal region of the general mantle surface, showing them to be of the simple cilia (SC) type 
mantle edge (Fig. 2a-d,f). The mantle surface was thus divided into 2 antero-posterior bands, each characterized by a specific cilia type.

\section{Spisula solidissima (Fig. 3)}

As in the preceding species, the mantle rejection tract extended antero-posteriorly along the ventral mantle margin to the dorsal-most base of the inhalent siphon (Fig $3 a-c$ ). In contrast to Mya arenaria, the mantle of Spisula solidissima presented a dorsal band of SC, an intermediate band of SCC, and a ventral band of LCC (Fig. 3d-f) corresponding to the rejection tract previously observed using video endoscopy (Beninger et al. 1997a). The LCC (20-25 $\mu \mathrm{m})$ of the mantle rejection tract were characterized by a greater density compared to the CC outside the tract (Fig. 3b-e).

\section{a}

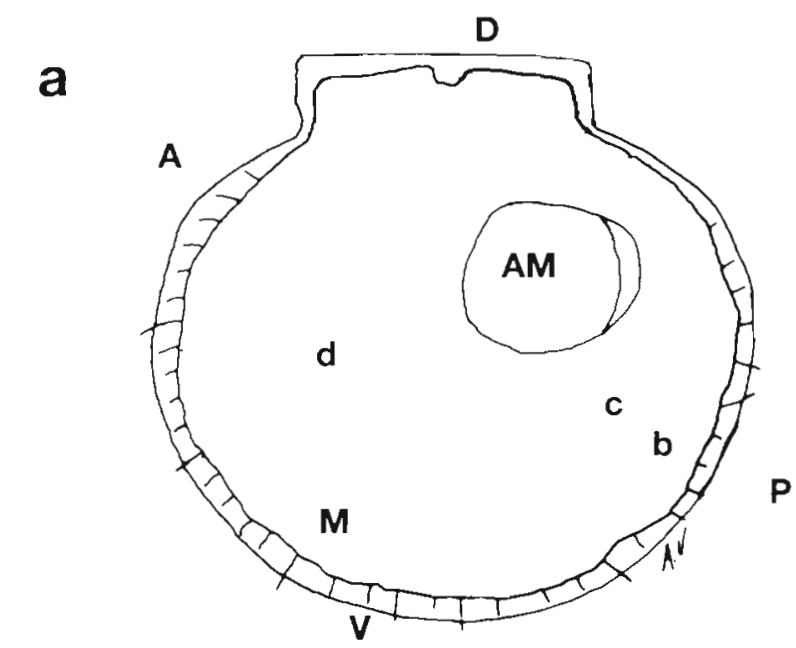

\section{Placopecten magellanicus (Fig. 4)}

The mantle ciliation of Placopecten magellanicus consisted of widely spaced tufts of LSC measuring approx. $15 \mu \mathrm{m}$ in length. No pattern was discernible in the distribution of these tufts, and no region was more densely ciliated than another (Fig. $4 \mathrm{a}-\mathrm{d}$ ). No CC were observed anywhere on the mantle.

\section{DISCUSSION}

Although only specimens $\leq 30 \mathrm{~mm}$ were used (due to the technical reasons given previously), it is unlikely that the features described are limited to small individuals. Few studies of the post-metamorphic development of bivalves have been performed, but observations of particle behaviour on the mantles of larger
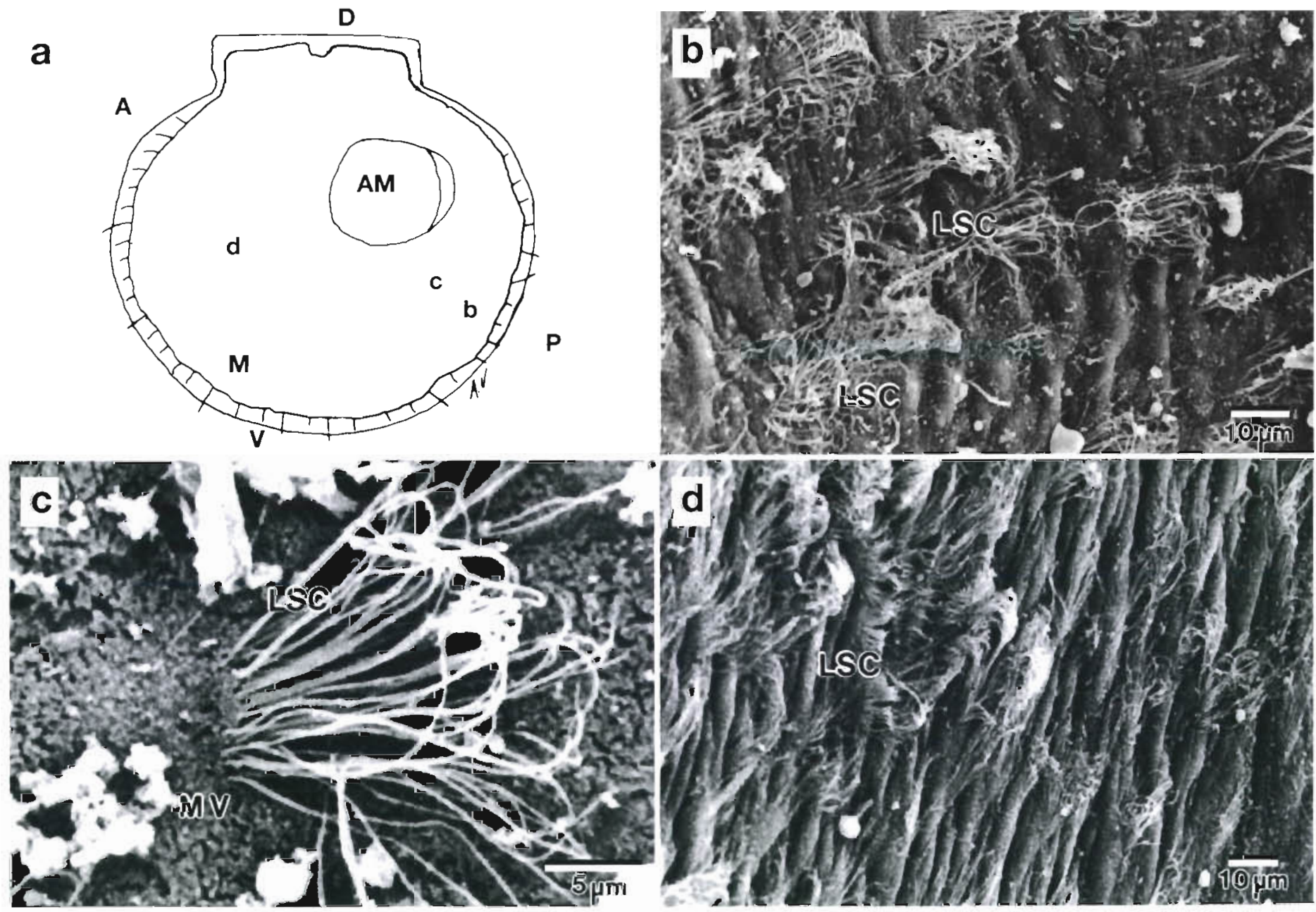

Fig. 4. Placopecten magellanicus mantle ciliation. (a) Location of SEM (lower-case letters corresponding to b-d). A, D, P, V: anterior, dorsal, posterior, and ventral regions, respectively. AM: adductor muscle. (b) SEM showing sparse mantle ciliation in posterior region of mantle, consisting of tufts of long simple cilia (LSC). (c) Detail of tuft of long simple cilia (LSC), showing surrounding microvilli (MV). (d) Sparsely distributed tufts of long simple cilia (LSC) in anterior region of mantle 
specimens confirm the location of the specialised ciliated rejection tracts reported in this study (Kellogg 1915, Ansell 1961, Beninger \& St-Jean 1997b, Beninger et al. 1997a).

\section{Mytilus edulis - the homorhabdic filibranch system}

The location of the antero-posterior tract of $\mathrm{CC}$ in Mytilus edulis corresponds to the location of the mantle rejection tract as previously observed using video endoscopy (Beninger \& St-Jean 1997b). In addition, this tract presents a remarkable density of AMPSsecreting mucocytes, compared to the general pallial surface (Beninger \& St-Jean 1997b); these secretions are essential for the counter-current transport of pseudofeces on the mantle. In $M$. edulis then, the rejection tract is characterized by the vertical elevation of transported material above the reach of the surrounding cilia of the general pallial surface (accomplished by the $\mathrm{CC}$ ) and by the use of high-viscosity AMPS which firmly bind rejecta transported counter to the prevailing current. The mucociliary transport of the pseudofeces presumably conforms to the 2-layer model (Lucas \& Douglas 1934, Silberberg et al. 1977, Yates et al. 1980, Blake \& Fulford 1984, Sleigh et al. 1988, Sleigh 1989), recently observed directly in $M$. edulis (Beninger et al. 1997b).

\section{Mya arenaria and Spisula solidissima- the eulamellibranch system}

In both Mya arenaria and Spisula solidissima, the location of the CC and LCC, respectively, corresponds to the location of the respective mantle rejection tracts, as previously observed using video endoscopy (Beninger et al. 1997a). The rejection tracts are situated closer to the mantle margin than in Mytilus edulis, but their endpoint is the same: the base of the inhalent siphon. The gill junctions in eulamellibranchs are located close to the dorsal region of the mantle, well beyond the ciliated rejection tract.

The data of the present study corroborate and extend those of Ansell (1961), who described the location of the mantle rejection tract in 12 eulamellibranch species, based on the behaviour of inert particles or of the alga Phaeodactylum sp. deposited on the mantle. In addition, his histological observations suggested that the cilia within the rejection tract were longer than those without, although the technique did not allow the distinction of simple and composite cilia. The results of Ansell (1961) and of Beninger et al. (1997a) are at variance with those of Wallengren (1905) and Yonge (1923), who described a much more com- plex trajectory for pseudofeces on the mantle in Mya arenaria

In both species of eulamellibranchs studied here, the pseudofeces rejection tract consists of $\mathrm{CC}$ whose length is greater than the cilia of the general mantle surface, thus permitting the vertical isolation of transported rejecta. Interestingly, whereas in Mya arenaria the general mantle surface presents SC, that of Spisula solidissima presents a gradation from $\mathrm{SC}$ dorsally to an intermediate band of $\mathrm{CC}$, and the vertical isolation is provided by LCC within the rejection tract.

Although mucocyte counts were not performed in the present study, Ansell (1961) observed AMPS (alcianblue positive) glands below the mantle epithelium, with ducts opening to the pallial surface in the 12 species of eulamellibranchs studied. These observations suggest that the use of AMPS on mantle rejection tracts is a general feature in bivalves possessing such tracts.

\section{Placopecten magellanicus- the heterorhabdic filibranch system}

The absence of a distinct ciliated tract on the Placopecten magellanicus mantle corresponds to the voidance of pseudofeces via valve clapping rather than by mucociliary transport to the inhalent siphon (Yonge 1967, Morton 1979 and authors' pers. obs.). Similarly, the lack of a distinct tract of AMPS (Beninger \& St-Jean 1997 b) underscores the absence of a voidance system based on mucociliary transport. Like all pectinids, and in contrast to the other 3 species of the present study, $P$. magellanicus does not possess a gill ventral particle groove (Beninger et al. 1988), and hence pseudofeces may be dislodged hydrodynamically from the ventral bend of the gill at any point along its course. The ciliated mantle epithelium is therefore bereft of a pseudofeces clearance function, corresponding to a lack of ciliary specialization.

\section{Unifying principles}

The foregoing considerations converge to present a set of unifying principles regarding pseudofeces elimination in the 3 systems studied.

(1) Types of bivalves possessing ciliated mantle pseudofeces rejection tracts

Antero-posterior, infrabranchial pseudofeces rejection tracts are necessary in bivalves which deposit pseudofeces in the anterior region, and which must transport these rejecta to the posterior region. This 
situation is the rule for bivalves which possess a gill ventral particle groove, since pseudofeces can only be deposited by the palps in such a system, and the inhalant siphon is confined to the posterior end of the bivalve. The vast majority of bivalve families conform to this configuration, represented here by Mytilus edulis, Mya arenaria, and Spisula solidissima. Notable exceptions are the monomyarians which void pseudofeces by valve clapping: the superfamilies Pectinacea and Limacea (Yonge 1967, Morton 1979), represented here by Placopecten magellanicus (Table 1).

(2) Distinguishing features of mantle pseudofeces rejection tracts

All mantle pseudofeces rejection tracts examined in the present study and in Ansell (1961) present both an elevation of rejecta above the general pallial surface, as well as the presence of a considerable density of AMPS mucocytes, which ensures counter-current transport (see Beninger \& St-Jean 1997b), and reduces the risk of re-suspension in the pallial cavity. Elevation thus provides the essential vertical isolation from the rest of the ciliated mantle surface.

Two mechanisms of horizontal isolation may also characterize mantle rejection tracts. The first of these is their location distal to the gill ventral particle groove. In all 3 of the species studied which possess mantle rejection tracts, the tracts are located far from the gill ventral particle groove. In the 2 eulamellibranchs, which have small gills and a ventral particle groove extending only one-third to one-half of the distance from the dorsal hinge to the shell edge, the mantle rejection tracts are situated in the ventralmost region of the mantle. In Mytilus edulis, where the gill and its ventral particle groove extend almost to the mantle edge, the mantle particle groove is situated in the dorsalmost part of the infrabranchial region of the mantle. The location of the mantle rejection tract far from the gill ventral particle groove would function to prevent entangling the antero-posterior travelling rafts of pseudofeces with the postero-anterior travelling strings of unsorted particles on their way to the labial palps. The second mechanism of horizontal isolation is the presence of protective mantle folds in the living specimen. Such mantle folds have been reported for numerous species (Kellogg 1915, Yonge 1948, 1949, 1952, 1953, Beninger et al. 1997a), and appear to be the result of the contraction of mantle muscles along one or both of the dorsal and ventral boundaries of the rejection tract. Folds of this type have been reported in undissected living specimens observed using video endoscopy (Beninger et al. 1997a), but are not always evident in fixed specimens (present study).

\section{(3) Characteristics of cilia in mantle rejection tracts}

In the 3 species possessing mantle rejection tracts examined here, vertical elevation of the pseudofeces was accomplished by extraordinarily long cilia. Extraordinarily long simple cilia are presumed to lack the required resilience to propel a mucus raft (Sleigh et al. 1988. Sleigh 1989), and in the 3 cases presented here, the rejection tract cilia were grouped to form composite cilia; the individual component cilia are thus able to provide mutual support, thus greatly increasing the propulsive efficiency (Sleigh et al. 1988, Sleigh 1989). From the SEM micrographs of the present study, the mechanism of inter-ciliary adhesion appears to be less intimate than that of compound cilia, which are actually fused for much of their length (Warner 1974). Detailed studies of this aspect are in progress; it appears likely that whenever extraordinarily long cilia are required to propel a mucus raft, they will be grouped in some way.

One major suspension-feeding system was not included in the present study of pseudofeces rejection pathways on the mantle: the pseudolamellibranch. Investigations have been completed on this system, which presents a unique combination of morphological characteristics: a heterorhabdic gill with a ventral particle groove and monomyarian condition derived from the superfamily Ostreacea.

\section{Mantle pseudofeces rejection mechanisms in the overall context of bivalve particle processing}

Studies on the mechanisms of suspension-feeding in bivalves have revealed a hitherto unsuspected complexity in particle processing. In hindsight, this is not surprising, considering the inherent complexity of feeding on a heterogeneous suspension of microscopic particles. Nevertheless, unifying principles are emerging from the information available over the past decade.

All available data to this point indicate that suspension-feeding bivalves present 3 levels of specialisation in particle processing: morphological (different pallial organ configurations corresponding to differences in processing sites and mechanisms; Beninger et al. 1992, 1997a, Ward et al. 1993, 1994, Beninger \& St-Jean $1997 a, b)$, biochemical (different MPS types accomplishing different processing functions; Beninger et al. 1993, Beninger \& Dufour 1996, Beninger \& St-Jean $1997 \mathrm{a}, \mathrm{b})$, and ciliary, with specific ciliary types effecting different functions, such as particle interception (Silverman et al. 1996) or various types of transport, as demonstrated in the present study.

The ciliary mapping approach used in the present study thus provides important information on bivalve 
suspension-feeding mechanisms unavailable from other techniques such as endoscopy, and is therefore an important element in the array of complementary methods currently in use.

Acknowledgements. We thank Mr L. Blanchard for his excellent photographic services. This study was supported by research grants to P.G.B. from the Natural Sciences and Engineering Research Council of Canada, and from the Faculté des études supérieures et de la recherche de l'Université de Moncton.

\section{LITERATURE CITED}

Ansell AD (1961) The functional morphology of the British species of Veneracea (Eulamellibranchia). J Mar Biol Assoc UK 41:489-515

Bayne BL, Newell RC (1983) Physiological energetics of marine molluscs. In: Saleuddin ASM, Wilbur KM (eds) The Mollusca, Vol 4, Physiology, Part 1. Academic Press, New York, p 407-515

Beninger PG, Dufour SC (1996) Mucocyte distribution and relationship to particle transport on the pseudolamellibranch gill of Crassostrea virginica (Bivalvia: Ostreidae). Mar Ecol Prog Ser 137:133-138

Beninger PG, St-Jean SD (1997a) Particle processing on the labial palps of Mytilus edulis and Placopecten magellanicus (Mollusca: Bivalvia). Mar Ecol Prog Ser 147:117-127

Beninger PG, St-Jean SD (1997b) The role of mucus in particle processing by suspension-feeding marine bivalves: unifying principles. Mar Biol 129:389-397

Beninger PG, Le Pennec M, Salaün M (1988) New observations of the gills of Placopecten magellanicus (Mollusca: Bivalvia) and implications for nutrition. I. General anatomy and surface microanatomy. Mar Biol 98:61-70

Beninger PG, Ward JE, MacDonald BA, Thompson RJ (1992) Gill function and particle transport in Placopecten magellanicus (Mollusca: Bivalvia) as revealed using video endoscopy. Mar Biol 114:281-288

Beninger PG, St-Jean S, Poussart Y, Ward JE (1993) Gill function and mucocyte distribution in Placopecten magellanicus and Mytilus edulis (Mollusca: Bivalvia): the role of mucus in particle transport. Mar Ecol Prog Ser 98: $275-282$

Beninger PG, Potter TM, St-Jean SD (1995) Paddle cilia fixation artefacts in pallial organs of adult Mytilus edulis and Placopecten magellanicus (Mollusca, Bivalvia). Can J Zool 73:610-614

Beninger PG, Dufour SC, Bourque J (1997a) Particle processing mechanisms of the eulamellibranch bivalves Spisula solidissima and Mya arenaria. Mar Ecol Prog Ser 150: $157-169$

Beninger PG, Lynn JW, Dietz TH, Silverman H (1997b) Mucociliary transport in living tissue: the two-layer model confirmed in the mussel Mytilus edulis L. Biol Bull 193:4-7

Blake JR, Fulford GR (1984) Mechanics of ciliary transport. Physico Chem Hyd 5:401-411

Dame RF (1993) The role of bivalve filter feeder material fluxes in estuarine ecosystems. In: Dame RF (ed) Bivalve filter feeders in estuarine and coastal ecosystem processes. Springer-Verlag, Berlin, p 245-269

Elsey CR (1935) On the structure and function of the mantle and gill of Ostrea gigas (Thumberg) and Ostrea Iurida (Carpenter). Trans R Soc Can 29(Section V):131-158+5 pl
Foster-Smith RL (1975) The role of mucus in the mechanism of feeding in three filter-feeding bivalves. Proc Malac Soc Lond 41:571-588

Iglesias JIP, Navarro E, Alvarez Jorna P, Armentia I (1992) Feeding, particle selection, and absorption in cockles Cerastoderma edule (L.) exposed to variable conditions of food concentration and quality. J Exp Mar Biol Ecol 162: $177-198$

Jørgensen CB (1966) The biology of suspension feeding. Pergamon Press, Oxford

Kautsky N, Evans S (1987) Role of biodeposition by Mytilus edulis in the circulation of matter and nutrients in a Baltic coastal ecosystem. Mar Ecol Prog Ser 38:201-212

Kellogg JL (1915) Ciliary mechanisms of lamellibranchs with descriptions of anatomy. J Morph 26:625-701

Lucas AM, Douglas LC (1934) Principles underlying ciliary activity in the respiratory tract II. A comparision of nasal clearance in man, monkey, and other mammals. Arch Otolaryngol 20:518-541

Morrisson CM (1993) Histology and cell ultrastructure of the mantle and mantle lobes of the eastern oyster, Crassostrea virginica (Gmelin): a summary atlas. Am Malacol Bull 10: $1-24$

Morton B (1979) A comparison of lip structure and function correlated with other aspects of the functional morphology of Lima Lima, Limaria (Platilimaria) fragilis, and Limaria (Platilimaria) hongkongensis sp nov (Bivalvia: Limacea). Can J Zool 57:728-742

Orton JH (1912) The mode of feeding of Crepidula, with an account of the current-producing mechanism in the mantle cavity, and some remarks on the mode of feeding in gastropods and lamellibranchs. J Mar Biol Assoc UK 9: $444-478$

Owen G (1966) Feeding. In: Wilbur KM, Yonge CM (eds) Physiology of Mollusca, Vol II Academic Press, New York, p $1-96$

Reindl S, Haszprunar G (1996) Fine structure of caeca and mantle of arcoid and limopsoid bivalves (Mollusca: Pteriomorpha). Veliger 39:101-116

Sierzen ME, Frost TM (1992) Selectivity in suspensionfeeders: food quality and the cost of being selective. Arch Hydrobiol 123:257-273

Silberberg A, Meyer FA, Gilboa A, Gelman RA (1977) Function and properties of epithelial mucus. In: Epstein $M$, Parke OV (eds) Advances in experimental medicine and biology 89. Plenum Press, New York, p 171-180

Silverman H, Lynn JW, Dietz TH (1996) Particle capture by the gills of Dreissena polymorpha: structure and function of latero-frontal cirri. Biol Bull 191:42-54

Sleigh MS (1989) Adaptations of ciliary systems for the propulsion of water and mucus. Comp Biochem Physiol 94A:359-364

Sleigh MS, Blake JR, Liron N (1988) The propulsion of mucus by cilia. Am Rev Resp Dis 137:726-741

Tankersley RA, Dimock RV Jr (1993) Endoscopic visualization of the functional morphology of the ctenidia of the unionid mussel Pyganodon cataracta. Can J Zool 71:811-819

Wallengren H (1905) Zur Biologie der Muscheln. II. Die Nah.rungsaufnahme. Kongl Fysiografiska Sällskapets Hand NF 16:1-59

Ward JE, Beninger PG, MacDonald BA, Thompson RJ (1991) A new technique for direct observations of feeding structures and mechanisms in bivalve molluscs using endoscopic examination and video image analysis. Mar Biol 111:287-291

Ward JE, MacDonald BA, Thompson RJ, Beninger PG (1993) Mechanisms of suspension-feeding in bivalves: resolution 
of current controversies by means of endoscopy. Limnol Oceanogr 38:265-272

Ward JE, Newell RIE, Thompson RJ, MacDonald BA (1994) In vivo studies of suspension-feeding processes in the eastern oyster, Crassostrea virginica (Gmelin). Biol Bull 186:221-240

Warner FD (1974) The fine structure of the ciliary and flagellar axoneme. In: Sleigh MA (ed) Cilia and flagella Academic Press, New York, p 11-37

Yates GT, Wu TY, Johnson RE, Cheung ATW, Frand CL (1980) A theoretical and experimental study on tracheal muco-ciliary transport. Biorheology 17:151-162

Yonge CM (1923) Studies on the comparative physiology of digestion. I. The mechanism of feeding, digestion, and assimilation in the lamellibranch Mya. Br J Exp Biol 1 : $15-63$

Editorial responsibility: Otto Kinne (Editor),

Oldendorf/Luhe, Germany
Yonge CM (1948) Cleansing mechanisms and the function of the fourth pallial aperture in Spisula subtruncata (Da Costa) and Lutraria lutraria (L). J Mar Biol Assoc UK 27. $585-596$

Yonge CM (1949) On the structure and adaptations of the Tellinacea, deposit-feeding Eulamellibranchia. Phil Trans R Soc Lond B 234;29-76

Yonge CM (1952) Studies on Pacific coast molluscs. IV. Observations on Siliqua patula Dixon and on evolution within the Solenidae. Univ Calif (Berkeley) Publs Zool 55: $421-438$

Yonge CM (1953) Form and habit in Pinna carnea Gmelin Phil Trans R Soc Lond B 237:335-374

Yonge CM (1967) Observations on Pedum spondyloideum (Chemnitz) Gmelin, a scallop associated with reef-building corals. Proc Malac Soc Lond 37:311-323

Submitted: June 22, 1998; Accepted: November 18, 1998

Proofs received from author(s): March 11, 1999 